\title{
Factors Affecting Business Continuity In The Smes Sector
}

\author{
Dela Ayu Kaswadi ${ }^{1 *}$, Noor Huda ${ }^{2}$ Krisna Puji Rahayu ${ }^{3}$ Intania Sari ${ }^{4}$ Retno \\ Setyowati ${ }^{5}$ Novia Kurniawati ${ }^{6}$ Aris Eddy Sarwono ${ }^{7}$ \\ 1,2,3,4,5,6,7 Economic Faculty, University of Slamet Riyadi Surakarta Indonesia \\ ${ }^{*}$ Corresponding author: \\ Email: aris_sarnur@yahoo.co.id
}

\begin{abstract}
.
This study aims to analyze the effect of E-Marketing and Financial Inclusion variables on the sustainability of Lurik Weaving SMEs in Klaten Regency, Central Java. The data source of this research uses primary data sources by using questionnaires. Respondents in this study were Lurik weaving SMEs, totaling 57 SMEs. The sampling technique uses a purposive technique with a convenience approach. The results of the analysis show that the use of the E Marketing strategy can improve the level of sustainability of Lurik Weaving SMEs, while the financial inclusion variable does not have a significant impact on the sustainability of SMEs. In addition, this analysis also uses control variables for the age of SME managers and the length of business of SMEs. The results of the analysis show that the length of business for SMEs can have an impact on the sustainability of SMEs.
\end{abstract}

Keywords: E-Marketing, Sustainability, SMEs, Length of Business, Lurik Weaving

\section{INTRODUCTION}

In Indonesia, the role of small and medium enterprises (SMEs) in the economic growth of a country is considered to have an important war. SMEs have a major contribution to the Indonesian economy. The criteria for SMEs are SMEs have productive economic activities that stand alone [1]. This business is carried out by individuals or business entities that are not subsidiaries or branches of companies that are owned, controlled or become a part, either directly or indirectly, of a medium or large business and meet other criteria.In general, SMEs have several characteristics, one of which uses limited capital. The success or failure of SMEs basically does not depend on the size of the business, but is more influenced by how manage it. Besides that, in running a business, of course there are several important factors that can maintain business continuity, This is an incentive to keep running their business.

However, SMEs today must be able to quickly respond to market changes appropriately, be long-term oriented, efficient in the use of technology, environmentally friendly, have technological innovation, and be in line with the principles of conserving natural resources and the environment [2]. On the other hand, the role of information technology in current conditions has an important role to support competitive advantage and business sustainability.Mastery of technology for SMEs really needs to be applied to business activities to increase their competitiveness. The emergence of information technology, especially the internet, will change the way in business by providing new opportunities and challenges that are different from 
conventional methods, especially in the current state of the COVID-19 pandemic. The need for digital communication access increases access to trade, marketing, job opportunities, income opportunities, and is able to provide added value [3]. This condition will have a positive impact on increasing efficiency, service, service quality, and expanding product access. In Indonesia, only 59.8 percent of SMEs use the internet as a means of communication [4]. This condition illustrates that SMEs have not been able to maximize the existence of information technology in supporting the development of SMEs.

In the current COVID-19 pandemic, SMEs are required to be able to adapt to the new (new normal), therefore they need the ability to survive by selling through digital marketing. SMEs are required to be able to promote products intensively by doing marketing using digital marketing and utilizing social media to be able to reach consumers directly by reducing promotional costs. Digital marketing helps SMEs in promoting and marketing their products and being able to expand new markets that were previously closed or limited due to limited time, distance and ways of communicating [5]. According to the results of the study, e-marketing has an effect on the marketing performance of SMEs [6], different research results state that ecommerce has a positive and insignificant effect on the performance of SMEs [7]. Research states that e-commerce has an effect on business continuity [8]. These results contradict other studies which state that e-commerce has a positive and insignificant effect on the performance of SMEs [7].

The Covid-19 pandemic has had an impact on the financial condition of the SME sector. Under these conditions, SMEs need financial services to maintain the sustainability of their operations. Financial inclusion is defined as the ability of the community to use financial service products such as loans, financial technology, banking, insurance, and other financial products [9]. Financial inclusion requires financial literacy where SMEs understand the importance of using financial service products because the Covid 19 pandemic can cause a decrease in capital. SMEs need easy access to obtain funds/credit which is very important for the community in running SMEs [10]. Financial inclusion plays a role in improving people's welfare, encouraging the process of national economic recovery, and supporting community economic resilience during the pandemic, but SMEs do not yet have access to financing through banking. The results of the study stated that in his research stated that financial inclusion had a positive and significant effect on the performance of SMEs. [11]. The results of other studies also state that financial inclusion has an effect on the performance of SMEs [12]. Financial inclusion has a significant effect on the performance of small businesses [13], but another opinion states that financial inclusion has no effect on the performance and sustainability of SMEs [14]. 


\section{METHODS}

This research is a survey research with SMEs that produce lurik woven products. The type of data used in this study uses quantitative data types, while the data sources of this study use primary data. The source of this data was obtained from a questionnaire given to striated weaving SMEs. The population in this study are SMEs in the Klaten area, Central Java. The sampling technique in this study used purposive sampling with a convenience sampling approach in determining the respondents, namely the SMEs of lurik weaving. The number of samples used in this study were 57 respondents.Data collection techniques in this study using a questionnaire. The scale used in this research questionnaire is a 5-point Likert scale by giving a score of 1 to 5 . The 5-point Likert scale consists of Strongly Agree (SS) is given a score of 5, Agree (S) is given a score of 4, Disagree (KS) is given a score 3, Disagree (TS) was given a score of 2, Strongly Disagree (STS) was given a score of 1.

This data analysis uses the application of the Statistical Package for the Social Sciences (SPSS), which consists of; validity test, reliability test, classical assumption test (normality, multicollinearity), multiple linear regression analysis, partial test $(\mathrm{t})$, model accuracy test (F), coefficient of determination test $\left(\mathrm{R}^{2}\right)$.T-test analysis is used to show how much influence one independent variable individually in explaining the variation of the independent variable. In addition, the use of this analysis is also used to examine the effect of control variables on business sustainability variables in striated weaving SMEs. In this test, it is done by measuring the probability value of its significance, while the F test is used for the accuracy of the model of the influence of the independent variable partially on the dependent variable.

\section{RESULT AND DISCUSSION}

In this section, an analysis will be presented to answer the objectives of this research. The analysis was carried out using regression analysis testing. The results of the data quality analysis (validity and reliability tests) that were carried out showed that the questionnaire items used for both the dependent variable (business sustainability) and the independent variables (E-marketing and financial inclusion) were valid and reliable, therefore it was possible to test assumptions classical. Regression tests carried out include: Multicollinearity Test, Heteroscedasticity Test, Autocorrelation Test and Normality Test. The results of the tests carried out for the classical assumptions show that there is no violation of the classical assumptions. Therefore, the next test is regression analysis. Prior to the regression analysis, a descriptive analysis was conducted which described the condition of the respondents. In table 1 below will be presented the condition of the respondents based on gender.

Table 1.Respondent's Gender

\begin{tabular}{ccc}
\hline Type & \multicolumn{2}{c}{ Respondent } \\
\cline { 2 - 3 } Sex & Number & Percentase (\%) \\
\hline
\end{tabular}




\begin{tabular}{|c|c|c|}
\hline \multicolumn{3}{|c|}{ (people) } \\
\hline Man & 20 & 35 \\
\hline Women & 37 & 65 \\
\hline Total & 57 & 100 \\
\hline \multicolumn{3}{|c|}{ Table 2.Respondent's Education } \\
\hline Education & \multicolumn{2}{|c|}{ Respondent } \\
\hline & $\begin{array}{l}\text { Number } \\
\text { (people) }\end{array}$ & $\begin{array}{c}\text { Percentase } \\
(\%)\end{array}$ \\
\hline SD & 36 & 63 \\
\hline SMP & 13 & 23 \\
\hline SMA & 4 & 7 \\
\hline AKADEMI/DIP & 4 & 7 \\
\hline S1 & - & - \\
\hline Total & 57 & 100 \\
\hline
\end{tabular}

The results of the analysis in table 1 show that the majority of SMEs managers are female (65 percent), while the number of male SMEs managers is 35 percent. Table 2 shows an overview of the education level of SMEs managers. The results in table 2 state that the majority of SMEs managers are still low-educated, namely elementary school (elementary school). The next analysis is to perform a regression test to answer the research objectives that have been set. Based on the results of the analysis presented in table 3, it shows that the E-marketing variable (X1) has an effect on business continuity in SMEs $(\mathrm{Y})$, this is indicated by a significance probability value of 0.05 with a beta value of -0.410 . The section also explains that the low condition of Emarketing carried out by SMEs, has an impact on the low quality of business continuity in SMEs. For SMEs, E-marketing can help SMEs in promoting and marketing SME products. The results of this study are supported by previous research which states that E-marketing has an effect on the marketing performance of SMEs [6], but these results contradict other studies which state that E-commerce has no effect on the performance of SMEs [7]. The results of the analysis in table 3 also show that the financial inclusion variable has no impact on the sustainability of SMEs. These results indicate that the business continuity of the SME sector does not depend much on financial services. The results of this study are supported by the results of previous studies which state that financial inclusion has a positive and significant effect on the performance of SMEs [11] [12] [13], but the results of this study are different from other studies which state that financial inclusion has no effect on the performance and sustainability of SMEs. 14]. 
Table 3. Regression Analysis 1

\begin{tabular}{|c|c|c|c|}
\hline \multirow[t]{2}{*}{ Variable } & \multicolumn{3}{|c|}{ Equation } \\
\hline & Coefficient $t$ & $t$-test & Sig. \\
\hline \multicolumn{4}{|c|}{ Independen t Variable: } \\
\hline E-Marketing & $-0,410$ & $-3,104$ & 0,003 \\
\hline Financial Inclusion & 0,149 & ,642 & 0,524 \\
\hline$R^{2}$ & 0,202 & & \\
\hline $\operatorname{Adj} . R^{2}$ & 0,172 & & \\
\hline F-test & 6.824 & & 0,002 \\
\hline
\end{tabular}

The results of the analysis for the F test (table 3 ) states that the effect of the independent variable on the dependent variable (SME business continuity) with the test criteria if the p-value 0.05 and Ho is rejected if the p-value 0.05 . The results of the analysis obtained that the calculated $\mathrm{F}$ value was 6.824 with a p-value of $0.002<0.05$, so the model was right in predicting the influence of the independent variable. Meanwhile, table 3 also shows that the adjusted R square value of 0.172 means that it can be seen that the influence of the independent variable on the dependent variable is 17.2 percent while $82.8 \%$ is influenced by other factors outside the variables studied.

Table 4. Regression Analysis 2

\begin{tabular}{|c|c|c|c|}
\hline \multirow[t]{2}{*}{ Variable } & \multicolumn{3}{|c|}{ Equation } \\
\hline & Coefficient $t$ & t-test & Sig. \\
\hline \multicolumn{4}{|l|}{ Independent Varible: } \\
\hline E-Marketing & $-0,410$ & $-3,104$ & 0,003 \\
\hline Financial Inclusion & 0,149 & ,642 & 0,524 \\
\hline \multicolumn{4}{|l|}{ Variabel Kontrol: } \\
\hline Financial Inclusion & 0,101 & 2,059 & 0,044 \\
\hline Age & 0,009 & 0,610 & 0,550 \\
\hline$R^{2}$ & 0,269 & & \\
\hline $\operatorname{Adj} . R^{2}$ & 0,212 & & \\
\hline$F$-test & 4,776 & & 0,002 \\
\hline
\end{tabular}

The results of the analysis in table 4 show the use of regression analysis using the control variables for length of business and age. The use of control variables is carried out to see the extent to which business continuity in SMEs is seen from the length of business and the age of SMEs managers. Based on the analysis in table 4 shows that the length of the business has a big role in maintaining business continuity. With the experience of running SMEs, especially for striated weaving SMEs, business continuity will be better. 


\section{CONCLUSION}

Business continuity for SMEs during the COVID-19 pandemic is a desire for all SMEs. In Indonesia, the existence of SMEs has an important role in promoting equitable distribution of community welfare and becoming the backbone of the economy. There are many factors that can cause business continuity to be carried out properly, both from the aspect of production carried out, marketing aspects and capital aspects. The results of the analysis concluded that the marketing factor as one of the factors that have a big role in increasing the sustainability of SMEs. The marketing factor that can be done during the COVID-19 pandemic is on-line marketing (Emarketing). In addition, the supporting factor that is important in the sustainability of SMEs is the length of business factor. This is the experience of SMEs in running their business.

\section{ACKNOWLEDGMENTS}

The author would like to thank the Lurik Weaving UKM group for providing the opportunity to conduct research so that this research can be carried out. In addition, the authors also thank the Directorate of Learning and Student Affairs, Directorate General of Higher Education, Ministry of Education and Culture of the Republic of Indonesia for facilitating research and publication activities through the Holistic Program for Village Development and Empowerment (PHP2D).

\section{REFERENCES}

[1] Republik Indonesia, Undang-Undang Nomor 20 Tahun 2008 About Micro, Small, and Medium Enterprises.

[2] Novita. Robusta coffee agroindustry data processing design using modified wet processing technology based on clean production. [Dissertation]. 2012. Bogor Agricultural University.

[3] Servaes, J.. Communication for development: one world, multiple cultures. second printing. Hampton Press, Inc., Cresskill, New Jersey.2002.

[4] Research and Development. Agency for Research and Human Resources Development. 2013. White Paper. Jakarta [ID]: Depkominfo.2013

[5] Prabowo, W. A. The Influence of Digital Marketing on Organizational Performance With Intellectual Capital and Perceived Quality as Intervening Variables in the Three Star Hotel Industry in East Java. Journal of Marketing Management. Vol 12 (2), p. 101-112.2018

[6] Priyanto, Hery Priyanto, Mukhamad Najib and Stevia Septiani. Factors of E-Marketing Adoption and Its Influence on Marketing Performance of Culinary SMEs in Bogor City. Journal of Business Information Systems. Vol 02 No 02.2020

[7] Tiandra, Nanda, Denny Hambali, Nurasia, Nadhira Rosalina. Analysis of the Effect of ECommerce on Improving MSME Performance (Case Study on MSMEs in Sumbawa Regency). Indonesian Journal of Economics and Business. Vol. 04, No. 01, p. 610.2013 
[8] Christopher and Kristianti. Relationship of E-Commerce and Financial Literacy to Business Continuity in Boyolali. Accounting journal. Vol. 10, No.1, p. $1-12.2020$

[9] Adriani, Diana and I Gst. Bgs. Wiksuana. Financial Inclusion in Relation to the Growth of MSMEs and the Level of Community Welfare in the Province of Bali. E-Journal of Unud Management, Vol. 7, No. 12, p. $6420-6444.2018$

[10] Ningsih, Tri Nova and Abel Tasman. The influence of financial literacy and financial inclusion on the performance of MSMEs. Journal of Management and Entrepreneurship Studies. Vol 2 No 4, p. 151-160. 2020

[11] Yanti, Wira Iko Putri. The Effect of Financial Inclusion and Financial Literacy on MSME Performance in North Moyo District. Journal of Management and Business. Vol.2 No.1, p. 1-9. 2019.

[12] Septiani, Risa Nadya and Eni Wuryani. The Effect of Financial Literacy and Financial Inclusion on MSME Performance in Sidoarjo. E-Journal of Management. Vol. 9, No. 8, p. 3214-3236. 2020

[13] Sanistasya, Poppy Alvianolita., Kusdi Rahardjo and Mohammad Iqbal. The Effect of Financial Literacy and Financial Inclusion on Small Business Performance in East Kalimantan. Journal of Economics. Vol 14, No. 1, pp. 48-59. 2019.

[14] Generous, Tommy. The Influence of Literacy, Inclusion and Financial Management on the Performance and Sustainability of MSMEs (Study on Micro Business Actors, Universitas Brawijaya Students). FEB Student Scientific Journal. Vol 8 No 1, p. 1-10. 2019. 